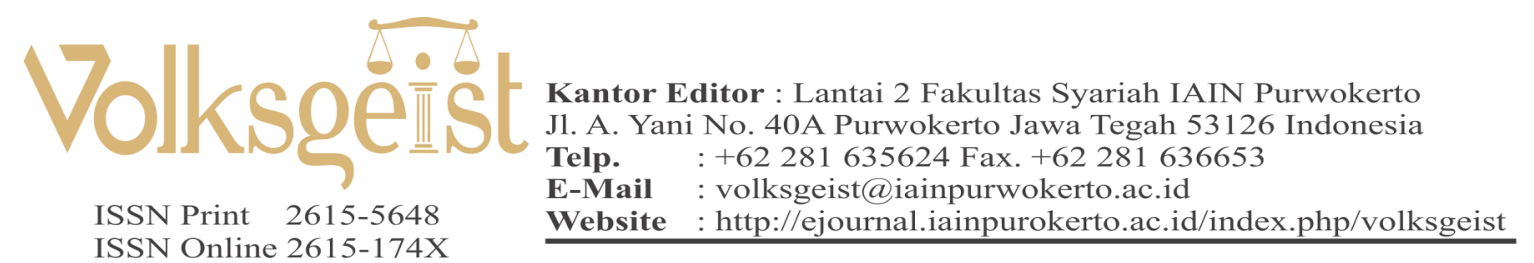

\title{
Penyelenggaraan Pemerintahan Daerah dalam Urusan Konkuren Bidang Pelayanan Dasar di Kota Serang
}

\author{
Rizki Ramadhan, ${ }^{1}$ Aidul Fitriciada Azhari \\ ${ }^{1}$ Universitas Muhammadiyah Surakarta \\ Email: ramaraizmadali89@gmail.com
}

\begin{abstract}
Abstrak
Artikel ini bertujuan untuk mengetahui dan menguraikan permasalahan tentang penyelenggaraan pemerintahan daerah dalam urusan konkuren bidang pelayanan dasar di Kota Serang. Diketahui untuk urusan yang berkaitan dengan pelayanan dasar berdasarkan Undang-Undang Nomor 23 Tahun 2014, diantaranya : a. Pendidikan; b. Kesehatan; dan c. Sosial. Artikel ini merumuskan masalah : 1. Apa saja permasalahan di Kota Serang ? 2. Faktor-Faktor apa yang mempengaruhi penyelenggaraan pemerintahan daerah bidang pendidikan, kesehatan, dan sosial di Kota Serang ?. Penulis mengidentifikasi menjadi empat pokok permasalahan yaitu : a. Belum optimalnya kondisi dan ketersediaan infrastruktur wilayah; b. Belum optimalnya inovasi dan rendahnya daya saing perekonomian daerah; c. Belum optimalnya penyelenggaraan tata kelola pemerintahan; dan d. Belum optimalnya penyelenggaraan pemerintahan daerah bidang pendidikan, kesehatan, dan sosial. Penelitian ini termasuk kedalam jenis penelitian deskriptif analitis. Dari empat permasalahan diatas, pemerintah daerah harus segera merancang dan menata kembali program skala prioritas dalam rencana kerja setiap satu tahun yang dikenal dengan Rencana Kerja Pembangunan Daerah (RKPD) dan pada akhirnya diharapkan berdampak besar bagi masyarakat serta terlaksananya pemerintah daerah berdasarkan prinsip good governance.
\end{abstract}

Kata Kunci: pemerintah daerah, kewenangan, urusan konkuren

\begin{abstract}
This article aims to identify and describe problems regarding the implementation of local government in concurrent affairs of the basic services in Serang. Basic services based on Law Number 23 of 2014, include: a. education; b. Health; and c. Social. This article formulates the following problems: 1. What are the problems in Serang?, 2. What factors that influence the implementation of local government in education, health, and social affairs in Serang?. The author identifies four main problems: a. The condition and availability of regional infrastructure is not optimal; $b$. lack of innovation and low competitiveness of the regional economy; c. The implementation of governance is not yet optimal; and d. The implementation of local government in education, health and social affairs is not yet optimal. This research uses analytical descriptive research. Based on the four problems mentioned earlier, the local government should immediately design and reorganize priority scale programs in the Regional Development Work Plan (RKPD). It is hoped that it will have good impact toward the community and the implementation of local government based on the principles of good governance.
\end{abstract}

Keywords: local government, authority, concurrent affair 


\section{Sejarah Artikel}

Dikirim: 02 Mei 2021

Direview: 12 Juni 2021

Diterima: 25 Juni 2021

Diterbitkan: 29 Juni 2021

\section{PENDAHULUAN}

Plato menyatakan penyelenggaraan negara yang baik adalah yang berdasarkan pada hukum yang baik. ${ }^{1}$ Negara Indonesia sebagai negara yang berdaulat tentu memiliki suatu konstitusi, dalam Undang-Undang Dasar 1945 Pasal 1 ayat (1) menyatakan bahwa "Negara Indonesia ialah Negara Kesatuan, yang berbentuk Republik", sebagai negara kesatuan dan memiliki konstitusi yang jelas tentu kewajiban negara adalah memperkuat bentuk negara, cara memperkuat bentuk negara tersebut dinyatakan pada Undang-Undang Dasar 1945 Pasal 37 ayat (5) bahwa "Khusus mengenai bentuk Negara Kesatuan Republik Indonesia tidak dapat dilakukan perubahan". Hukum pada pokoknya adalah produk pengambilan keputusan ditetapkan oleh fungsi-fungsi kekuasaan negara yang mengikat subjek hukum dengan hak-hak dan kewajiban hukum berupa larangan (prohibere), atau keharusan (obligatere), ataupun kebolehan (permittere). ${ }^{2}$

Diketahui dalam negara kesatuan (unitary state) memiliki dua sistem yaitu: sistem sentralisasi (unitary state by centralization) dan sistem desentralisasi (unitary state by decentralization). Negara kesatuan dengan sistem desentralisasi memiliki lima varian model yaitu:

1. Negara kesatuan dengan sistem desentralisasi yang sentralistik;

2. Negara kesatuan sistem desentralisasi yang desentralistik;

\footnotetext{
1 Nurul Qamar, Hak Asasi Manusia Dalam Negara Hukum Demokrasi (Jakarta Timur: Sinar Grafika, 2013), 24.

2 Jimly Asshiddiqie, Perihal Undang-Undang (Jakarta: Rajawali Pres, 2011), 7.
}

3. Negara kesatuan sistem desentralisasi yang proporsional;

4. Negara kesatuan sistem desentralisasi yang federalistik;

5. Negara kesatuan sistem desentralisasi yang konfederalistik. ${ }^{3}$

Dari lima macam varian model di atas, ternyata Indonesia pernah menggunakan desentralisasi federalistik yang dijalankan dalam UU No. 22 Tahun 1999 dan UU No. 32 Tahun $2004{ }^{4}$

Mengaktualisasikan tujuan nasional, tentu menimbulkan perubahan dalam undangundang pemerintahahan daerah, sehingga adanya perubahan antara pusat dan daerah yang begitu menarik untuk dikaji. Masalah timbul dalam prakteknya yaitu mengenai tarik menarik kepentingan jelas merupakan hal yang tidak dapat dihindarkan dan kelaziman negara yang berbentuk kesatuan adalah kewenangan yang diberikan oleh pusat kepada daerah sangat terbatas. ${ }^{5}$ Dari hal tersebut lahirlah Pemerintahan Daerah Kota Serang berdasarkan Undang-Undang Nomor 32 tahun 2007. Secara administratif Kota Serang dibagi dalam 6 kecamatan, 67 kelurahan, dan Kota Serang merupakan pusat pemerintahan Provinsi Banten.

Undang-Undang Nomor 23 Tahun 2014 telah memberikan kewenangan namun begitu terbatas dan terlihat tidak mudah bagi pemerintah untuk merelakan kekuasaan "devolusi" kepada daerah. ${ }^{6}$ Setelah diberikannya kewenan-

\footnotetext{
3 Astin Riyanto, Aktualisasi Negara Kesatuan Setelah Perubahan Atas Pasal 18 Undang-Undang Dasar Negara Republik Indonesia Tahun 1945 (Bandung: Disertasi Universitas Padjajaran, 2006), 73.

4 Mahmuzar, "Model Negara Kesatuan Republik Indonesia Di Era Reformasi," Jurnal Hukum Dan Pembangunan 50, no. 2 (2020): 33.

5 Ni'matul Huda, Hukum Pemerintahan Daerah (Bandung: Nusamedia, 2010), 1.

6 Achmad Fauzi, "Otonomi Daerah Dalam Kerangka Mewujudkan Penyelenggaraan Pemerintahan
} 
gan, tentu harus diperkuat dan pelayanan di pemerintahan daerah berdasarkan prinsip good governance sebagaimana proses penyelenggaraan pemerintahan daerah dalam rangka mewujudkan pemerintahan yang demokratis, bersih, transparan, dapat di pertanggungjawabkan, efektif dan efisien. ${ }^{7}$ Good governance merupakan wujud nyata dalam penyelenggaraan pemerintahan negara yang bersih atau tata kelola yang baik dan benar. ${ }^{8}$ Fakta dilapangan nyatanya perlu adaya percepatan atas kewenangan yang telah diberikan pemerintah ke pemerintah Kota Serang yang berstatus Ibukota Provinsi Banten dan tertinggalnya dalam pembangunan, hal ini diamini oleh Hasan Basri selaku Wakil Ketua DPRD Kota Serang 2019-2024 yang mengatakan "Memang belum ideal untuk disebut menjadi Ibukota Provinsi Banten, bahkan menyebutkan kalau daerahnya ini masih belum sepadan jika harus dibandingkan dengan daerah ibukota provinsi lain di Indonesia". ${ }^{9}$ Tentunya ini perlu adanya evaluasi dalam penyelenggaraan di pemerintahan Kota Serang yang merupakan ibukota provinsi, seyogyanya menjadi etalase kota yang harus berbenah diri dari berbagai aspek. Hal ini begitu sangat penting dikarenakan berdasarakan sumber informasi, bahwa Gubernur Banten mengaku malu mendengar keluhan kalau ibukota Provinsi Papua lebih baik ketimbang ibukota Provinsi Banten. ${ }^{10}$

Daerah Yang Baik," Jurnal Spektrum Hukum 16, no. 1 (2019): 121.

7 Yulia Neta, "Model Tata Kelola Administrasi Pemerintahan Yang Baik Di Daerah Otonom Baru," Fiat Justitia Jurnal Ilmu Hukum 6, no. 2 (Agustus 2012): 2.

8 Jopinus Saragih G, "Reformasi Aparatur Negara Untuk Melaksanakan Tata Kelola Pemerintahan Yang Baik Dan Benar (Good Governance," Majalah Ilmiah Widya 29, no. 319 (April 2012): 18.

9 "Kota Serang Dinilai Belum Layak Jadi Ibu Kota Provinsi | Republika Online," accessed June 21, 2021, https://www.republika.co.id/berita/q2e19d430/ kota-serang-dinilai-belum-layak-jadi-ibu-kota-provinsi.

10 "Kota Tak Ideal, Pemkot Serang Salahkan Provinsi Banten | Republika Online," accessed June 21, 2021, https://www.republika.co.id/berita/q54lww377/
Artikel ini merumuskan masalah: Apa saja permasalahan di Kota Serang dan faktorfaktor apa yang mempengaruhi penyelenggaraan pemerintahan daerah bidang pendidikan, kesehatan, dan sosial di Kota Serang. Sehingga artikel ini untuk mengetahui dan menguraikan permasalahan tentang penyelenggaraan pemerintahan daerah dalam urusan konkuren bidang pelayanan dasar di Kota Serang. Penelitian ini termasuk kedalam jenis penelitian deskriptif analitis, meliputi isi dan struktur hukum positif, yaitu suatu kegiatan yang dilakukan oleh penulis untuk menentukan isi atau makna suatu aturan hukum yang dijadikan rujukan dalam penyelesaian permasalahan hukum yang menjadi objek kajian. ${ }^{11}$ Teknik pengumpulan data menggunakan bahan hukum primer bersumber dari peraturan perundang-undangan dan bahan hukum sekunder meliputi buku-buku dan jurnal. ${ }^{12}$ Teknik data penelitian ilmiah ini berdasarkan studi dokumen dan observasi, data yang digunakan untuk menganalisis menggunakan analisis kualitatif.

\section{PEMBAHASAN}

\section{Negara Kesatuan dan Kewenangan Peme- rintahan Daerah.}

Negara merupakan organisasi besar yang dikelola secara bersama-sama, modern, dan terbuka. Negara menjadi tumpuan harapan dari rakyatnya untuk secara bersama-sama mencapai tujuan tertentu yang secara normatif digariskan oleh the founding father dan secara umum dituangkan dalam konstitusi. ${ }^{13}$ Negara merupakan gejala kehidupan umat manusia mod-

\footnotetext{
kota-tak-ideal-pemkot-serang-salahkan-provinsi-banten.

11 M. Zainuddin Ali, Metode Penelitian Hukum (Jakarta: Sinar Grafika, 2013), 107.

12 I.Made Pasek Diantha, Metodologi Penelitian Hukum Normatif Dalam Justifikasi Teori Hukum (Jakarta: Prenada Media, 2016), 8.

13 Samsul Wahidin, Distribusi Kekuasaan Negara Indonesia (Yogyakarta: Pustaka Pelajar, 2014), 5.
} 
ern, dimana konsep negaraberkembang mulai dari bentuknya yang paling sederhana sampai ke yang paling kompleks di zaman sekarang. Teori mengenai susunan organisasi negara yang selama berabad-abad dipahami terdiri atas tiga kemungkinan bentuk, yaitu negara kesatuan (unitary state atau eenheidsstaat), negara serikat atau federal (bondstaat), dan negara konfederasi (confederation). ${ }^{14} \mathrm{Kemu}-$ dian berkembang di zaman sekarang bentuk negara diklasifikasikan menjadi dua yaitu negara kesatuan (unitary state, eenheidsstaat) dan negara serikat (federal, bonds-staat) saja. ${ }^{15}$

Mengenai termenologi kesatuan dalam negara kesatuan diungkapkan oleh Jimly Asshiddiqie, bahwa istilah kesatuan yang bersifat persatuan itu harus dikembalikan kepada bunyi rumusan sila ketiga dalam Pancasila, yaitu Persatuan Indonesia bukan Kesatuan Indonesia yang dimana menurut jimly, persatuan istilah filsafat dan prinsip bernegara, sedangkan kesatuan adalah istilah bentuk negara yang bersifat teknis dan telah termaktub dalam UUD 1945 Pasal 1 ayat (1) yaitu "Negara Indonesia adalah Negara Kesatuan yang berbentuk Republik". Negara kesatuan merupakan konsepsi tentang bentuk negara dan republik adalah konsepsi mengenai bentuk pemerintahan yang dipilih dan telah ditetapkan pada UUD 1945. ${ }^{16}$ Diketahui Negara kesatuan memiliki dua sistem : sistem sentralisasi (unitary state by centralization) dan sistem desentralisasi (unitary state by decentralization). Dalam hal ini akan ditekankan pada negara kesatuan sistem desentralisasi, sebagaimana menurut C.F. Strong mengemukakan ciri negara kesatuan yang desentralistis yaitu kekuasaan tertinggi di Pemerintah

14 Jimly Asshiddiqie, Pengantar Ilmu Hukum Tata Negara (Jakarta: Sekretariat Jenderal dan Kepaniteraan MK RI, 2016), 6.

15 Dossy Iskandar Prasetyo dan Bernard L, Ilmu Negara (Surabaya: Srikandi, 2005), 33.

16 Jimly Asshiddiqie, Konstitusi Dan Konstitualisme (Jakarta: Konstitusi Press, 2006), 213.
Pusat, negara kesatuan yang didesentralisasikan, meskipun kekuasaan pemerintah dapat dilimpahkan kepada pemerintah daerah namun keputusan terakhir tetap berada di pemerintah pusat. ${ }^{17}$ Dalam negara kesatuan hanya ada satu pemerintah, yaitu pemerintah pusat. Pemerintah daerah dibentuk hanya untuk memudahkan dan mengoptimalkan pelaksanaan urusan pemerintah yang ada di daerah agar lebih sesuai dengan kebutuhan masyarakat daerah.

Jika dicermati berdasarkan konsep otonomi daerah, wewenang yang ada pada pemerintah daerah untuk mengurus dan mengatur rumah tangganya sendiri adalah merupakan wewenang delegasi, dalam hal ini Plilipus M. Hadjon menyatakan otonomi daerah pada dasarnya adalah wewenang delegasi. Untuk memperjelas perbedaan mendasar antara wewenang atribusi, delegasi, dan mandat, berikut ini skema tentang perbedaan tersebut: ${ }^{18}$

Tabel 1. Skema dari Perbedaan Sumber Kewenangan

\begin{tabular}{|c|c|}
\hline \multicolumn{2}{|c|}{ ATRIBUSI } \\
\hline $\begin{array}{l}\text { Cara } \\
\text { Perolehan }\end{array}$ & Perundang-undangan \\
\hline $\begin{array}{l}\text { Kekuatan } \\
\text { Mengikatnya }\end{array}$ & $\begin{array}{l}\text { Tetap melekat sebelum } \\
\text { ada perubahan peraturan } \\
\text { perundang-undangan }\end{array}$ \\
\hline $\begin{array}{l}\text { Tanggung } \\
\text { Jawab dan } \\
\text { Tanggung } \\
\text { Gugat }\end{array}$ & $\begin{array}{l}\text { Penerima wewenang } \\
\text { bertanggung jawab } \\
\text { mutlak akibat yang } \\
\text { timbul dari wewenang }\end{array}$ \\
\hline $\begin{array}{l}\text { Hubungan } \\
\text { Wewenang }\end{array}$ & $\begin{array}{l}\text { Hubungan hukum } \\
\text { pembentuk undang } \\
\text { undang dengan organ } \\
\text { pemerintahan }\end{array}$ \\
\hline
\end{tabular}

17 Bagir Manan, Perjalanan Historis Pasal 18 UUD 1945 (Jakarta: UNISKA, 1993), 3.

18 Sadjijono, Bab-Bab Pokok Hukum Administrasi (Yogyakarta: PRESSindo, 2008), 67. 


\begin{tabular}{|c|c|}
\hline \multicolumn{2}{|c|}{ DELEGASI } \\
\hline $\begin{array}{l}\text { Cara } \\
\text { Perolehan }\end{array}$ & Pelimpahan \\
\hline $\begin{array}{l}\text { Kekuatan } \\
\text { Mengikatnya }\end{array}$ & $\begin{array}{l}\text { Dapat dicabut atau di } \\
\text { tarik kembali apabila } \\
\text { ada pertentangan atau } \\
\text { penyimpangan }\end{array}$ \\
\hline $\begin{array}{l}\text { Tanggung } \\
\text { Jawab dan } \\
\text { Tanggung } \\
\text { Gugat }\end{array}$ & $\begin{array}{l}\text { Pemberi wewenang } \\
\text { (delegans) melimpahkan } \\
\text { tanggung jawab dan } \\
\text { tanggung gugat kepada } \\
\text { penerima wewenang } \\
\text { (delegataris) }\end{array}$ \\
\hline $\begin{array}{l}\text { Hubungan } \\
\text { Wewenang }\end{array}$ & $\begin{array}{l}\text { Berdasarkan atas } \\
\text { wewenang atribusi yang } \\
\text { dilimpahkan kepada } \\
\text { delegataris }\end{array}$ \\
\hline \multicolumn{2}{|c|}{ MANDAT } \\
\hline $\begin{array}{l}\text { Cara } \\
\text { Perolehan }\end{array}$ & Pelimpahan \\
\hline $\begin{array}{l}\text { Kekuatan } \\
\text { Mengikatnya }\end{array}$ & $\begin{array}{l}\text { Dapa ditarik atau di } \\
\text { gunakan sewaktu waktu } \\
\text { oleh pemberi wewenang }\end{array}$ \\
\hline $\begin{array}{l}\text { Tanggung } \\
\text { Jawab dan } \\
\text { Tanggung } \\
\text { Gugat }\end{array}$ & $\begin{array}{l}\text { Berada pada pemberi } \\
\text { mandat }\end{array}$ \\
\hline $\begin{array}{l}\text { Hubungan } \\
\text { Wewenang }\end{array}$ & $\begin{array}{l}\text { Hubungan yang bersifat } \\
\text { internal antara bawahan } \\
\text { dengan atasan }\end{array}$ \\
\hline
\end{tabular}

Secara teoritis penyerahan wewenang oleh pemerintah kepada pemerintah daerah dikenal sebagai sistem rumah tangga daerah. Sistem rumah tangga daerah adalah tatanan yang bersangkutan dengan cara membagi wewenang, tugas, dan tanggung jawab mengatur, mengurus urusan pemerintahan antara pusat dan daerah. ${ }^{19}$ Menurut Bagir Manan, wewenang dalam

19 Philipus Hadjon M. dkk, Pengantar Hukum Administrasi Indonesia, vol. IX (Yogyakarta: Gajah Mada University Press, 2005), 79. bahasa hukum tidak sama dengan kekuasaan (macht). Kekuasaan hanya menggambarkan hak untuk berbuat atau tidak berbuat. Dalam kaitan dengan otonomi daerah, hak mengandung pengertian kekuasaan untuk mengatur sendiri (zelfregelen) dan mengelola sendiri (zelfbesturen), sedangkan kewajiban secara horizontal berarti kekuasaan untuk menyelenggarakan pemerintahan sebagaimana mestinya. Vertikal berarti kekuasaan untuk menjalankan pemerintahan dalam satu tertib ikatan pemerintahan negara secara keseluruhan. ${ }^{20}$ Kewenangan diberikan secara atribusi kepada pemerintah daerah dalam penelitian ini dapat dilihat pada Undang-Undang Nomor 23 Tahun 2014 tentang Pemerintahan Daerah khususnya Bagian Ketiga urusan konkuren Pasal 11 dan 12. Urusan pemerintahan kokuren merupakan salah satu unsur dari klasifikasi urusan pemerintahan, sebagaimana diatur dalam Undang-Undang Nomor 23 Tahun 2014 tentang Pemerintahan Daerah. Definisi tentang urusan pemerintahan yang bersifat konkuren adalah urusan pemerintahan diluar urusan pemerintahan yang menjadi kewenangan sepenuhnya pemerintah, yang diselenggarakan bersama oleh pemerintah, pemerintahan daerah provinsi, dan pemerintahan daerah kabupaten/kota. ${ }^{21}$

Desentralisasi menurut Hoogerwarf merupakan pengakuan atau penyerahan wewenang oleh badan-badan publik yang lebih tinggi kepada badan-badan publik yang lebih rendah kedudukanya untuk secara mandiri dan berdasarkan kepentingan sendiri mengambil keputusan di bidang pengaturan (regelendaad) dan di bidang pemerintahan (bestuursdaad). ${ }^{22}$ Menurut M. Friedman menjelaskan bahwa susbtansi hukum perlu dibuat untuk mengatur dan

$20 \mathrm{dkk}, \mathrm{IX}: 102$.

21 PP Nomor 38 Tahun 2007 tentang Pembagian Urusan Pemerintahan Antara Pemerintah, Pemerintahan Daerah Provinsi, Dan Pemerintahan Daerah Kabupaten/ Kota, n.d.

22 Jimly Asshiddiqie, Pengantar Ilmu Hukum Tata Negara (Jakarta: Rajagrafindo Persada, 2015), 294. 
memperbaharui kehidupan masyarakat. ${ }^{23}$ Untuk itu adanya regulasi yang mengatur tentang urusan pemerintah konkuren, yang merupakan landasan hukum pelaksanaan otonomi daerah dan pembagian urusan pemerintahan antara pemerintah pusat dan daerah yaitu provinsi, kabupaten/kota.

Urusan pemerintahan wajib adalah urusan pemerintahan yang wajib diselenggarakan oleh pemerintahan daerah yang terkait dengan pelayanan dasar (basic services) bagi masyarakat, seperti pendidikan dasar, kesehatan, lingkungan hidup, sosial, kependudukan dan sebagainya. Urusan pemerintahan yang bersifat pilihan adalah urusan pemerintahan yang diprioritaskan oleh pemerintahan daerah untuk diselenggarakan yang terkait dengan upaya mengembangkan potensi unggulan (core competence) yang menjadi kekhasan daerah. ${ }^{24}$ Pemahaman kekuasaan dalam aspek hukum, dimaknai sebagai sebuah wewenang, tetapi kekuasaan dalam pengertian ini bukanlah suatu kekuasaaan yang dapat berdiri sendiri, melainkan keberadaan kekuasaan tidak dapat dipisah dari lembaganya, kekuasaan dalam arti wewenang dikatakan sebagai suatu kekuasaan yang telah dilembagakan. ${ }^{25}$ Oleh karena itu otonomi daerah pada akhirnya menimbulkan dampak yang sangat besar bagi pemerintahan daerah, hal ini dikarenakan dengan berlakunya undang-undang pemerintahan daerah maka pemerintahan daerah mempunyai wewenang penuh dalam mengadakan pembangunan di daerahnya. ${ }^{26}$

23 Hariyanto Hariyanto, "Pembangunan Hukum Nasional Berdasarkan Nilai-Nilai Pancasila," Volksgeist: Jurnal Ilmu Hukum Dan Konstitusi 1, no. 1 (June 7, 2018): 56-57, https://doi.org/10.24090/volksgeist. v1i1.1731.

24 PP Nomor 38 Tahun 2007 tentang Pembagian Urusan Pemerintahan Antara Pemerintah, Pemerintahan Daerah Provinsi, Dan Pemerintahan Daerah Kabupaten/ Kota Bagian Umum.

25 Jeddawi Murtir H, Negara Hukum Good Governance Dan Korupsi Di Daerah (Yogyakarta: Total Media, 2011), 5.

26 Rozali Abdullah, Pelaksanaan Otonomi Luas

\section{Permasalahan yang Terdapat Di Pemerintah Kota Serang.}

Pelaksanaan desentralisasi pada masa reformasi pada hakikatnya membawa angin segar bagi pemerintah daerah untuk berkiprah lebih nyata di tengah-tengah masyarakat yang diayominya. Namun, pada prinsipnya masyarakat tidak dapat menutup mata dari kendala empiris yang muncul dalam pelaksanaan desentralisasi khususnya dalam hal pembangunan daerah. Tentu pembangunan disuatu daerah harus melibatkan semua pihak, baik dari tingkat pusat sampai tingkat daerah termasuk kecamatan, kelurahan, hingga pihak swasta. Selanjutnya ditemukan permasalahan dalam pembangunan daerah di Kota Serang, dimana penulis mengidentifikasi menjadi tiga pokok permasalahan yang didapat berdasarkan penelitian pustaka dan lapangan yang telah diolah sebagai berikut:

1. Belum optimalnya kondisi dan ketersediaan infrastruktur wilayah, dengan penjelasan yaitu:

a. Ketersediaan dan kondisi jalan yang kurang memadai bagi terselenggaranya fungsi kota yang optimal (jalan kota dalam kondisi baik sebesar 65,50 persen dan jembatan dalam kondisi baik sebesar 84,62 persen), diiringi dengan problem kemacetan dan genangan air di beberapa titik ruas jalan, serta kondisi drainase yang kurang berfungsi dengan baik merupakan penyebab utama kerusakan jalan di samping tonase angkutan barang yang seringkali tidak terkendali;

b. Ketersediaan dan kondisi infrastruktur perhubungan yang kurang memadai, tergambar dari minimnya ketersediaan Penerangan Jalan Umum (PJU), belum optimalnya fungsi keberadaan halte dan rambu lalu lintas, penga-

Dengan Pemilihan Kepala Daerah Secara Langsung (Jakarta: PT Raja Grafindo Persada, 2005), 12. 
wasan trayek angkutan umum, dan pengolaan perparkiran dan terminal tidak terintegrasi;

c. Kondisi dan ketersediaan infrastruktur perumahan dan permukiman yang tergambar dari masih adanya kawasan kumuh sekitar 1,34 persen dari luas wilayah Kota Serang, rumah tangga bersanitasi sebesar 79,28 persen, rumah tangga pengguna air bersih sebesar 39,01 persen pada Tahun 2020;

d. Kondisi dan ketersediaan infrastruktur penunjang Smart City yang belum optimal dan memadai dalam mendukung pengelolaan dan implementasi teknologi informasi dalam tata kelola pemerintahan dan pelayanan publik. ${ }^{27}$

2. Belum optimalnya inovasi dan rendahnya daya saing perekonomian daerah, dengan penjelasan yaitu :

a. Masih adanya ketimpangan dan kemiskinan, dikarenakan belum optimalnya cakupan masyarakat miskin yang terlayani jaminan kesehatan, serta penanganan dan pemberdayaan sosial;

b. Tingginya tingkat pengangguran, dikarenakan rendahnya ketersediaan lapangan kerja, rendahnya minat kewirausahaan masyarakat, rendahnya kompetensi dan daya saing tenaga kerja sesuai kebutuhan pasar kerja, dan belum optimalnya pembinaan hubungan industrial;

c. Rendahnya daya saing dan pertumbuhan koperasi dan UMKM, disebabkan oleh rendahnya koperasi sehat, terbatasnya akses permodalanda pema-

27 Rancangan Perda Kota Serang Tahun 2021 Tentang Perubahan Atas Peraturan Daerah Kota Serang Nomor 3 Tahun 2019 Tentang RPJMD Kota Serang 2018-2023, n.d., IV-4. saran, rendahnya daya saing produk IKM;

d. Belum optimalnya pertumbuhan sektor perdagangan serta pengendalian stabilitas harga dan pasokan barang, yang disebabkan oleh belum optimalnya pengelolaan dan penataan pasar, serta belum optimalnya pembinaan pedagang dan PKL;

e. Belum optimalnya ketahanan pangan daerah, disebabkan oleh ketergantungan ketersediaan pangan utama dari daerah sekitar yaitu sebesar 80,00 persen;

f. Belum optimalnya jumlah dan daya saing produksi pertanian, belum optimalnya pembinaan terhadap petani dan nelayan, terbatasnya sarana dan prasarana pertanian dan perikanan;

g. Belum optimalnya pengelolaan pariwisata dan kontribusi pariwisata terhadap perekonomian daerah, disebabkan oleh belum optimalnya pengelolaan obyek dan destinasi wisata, infrastruktur penunjang wisata, dan promosi obyek dan destinasi wisata. ${ }^{28}$

3. Belum optimalnya penyelenggaraan tata kelola pemerintahan, dengan penjelasan yaitu :

a. Belum optimalnya integrasi sistem perencanaan, penganggaran, pengendalian dan pengelolaan keuangan dan aset daerah, implementasi SPIP dan kapabilitas APIP, sistem manajemen SDM aparatur, dan belum optimalnya pengelolaan keuangan dan aset daerah yang sudah hampir 14 tahun masih bersengketa dengan pemda Kabupaten Serang;

28 Rancangan Perda Kota Serang Tahun 2021 Tentang Perubahan Atas Peraturan Daerah Kota Serang Nomor 3 Tahun 2019 Tentang RPJMD Kota Serang 2018-2023, IV-6. 
b. Belum optimalnya pelayanan publik, disebabkan oleh belum optimalnya penyusunan dan penerapan SOP dan SPM, sarana prasarana pelayanan publik, penggunaan teknologi informasi dalam pelayanan publik, dan budaya kerja aparatur;

c. Masih adanya gangguan keindahan, ketentraman dan ketertiban (K3) yang disebabkan oleh kurangnya kesadaran dan kepatuhan masyarakat untuk menjaga keindahan, ketertiban dan ketentraman.

Dari tiga permasalahan diatas, pemerintah daerah harus segera merancang dan menata kembali program skala prioritas dalam rencana kerja setiap satu tahun yang dikenal dengan Rencana Kerja Pembangunan Daerah (RKPD) berdasarkan ketentuan Permendagri 90 Tahun 2019 tentang Klasifikasi, Kodefikasi, dan Nomenklatur Perencanaan Pembangunan dan Keuangan Daerah yang harus disesuaikan dengan perencanaan pembangunan nasional. Melihat fakta lapangan dan perlu di prioritaskan yang berdampak langsung terhadap masyarakat yaitu menyoal infrastruktur yang dikarenakan infrastruktur fasilitas umum 35\% masih belum memadai dan perlu segera dirampungkan. Kemudian program prioritas selanjutnya adalah penyelenggaraan tata kelola pemerintahan, karena ini merupakan hal yang langsung berhadapan dengan masyarakat khususnya mengenai pelayanan dan aset daerah yang sampai hari ini masih bersengketa dengan pemerintah daerah lain. Hal ini dinilai perlu segera dituntaskan karena ini merupakan kunci keberhasilan dan daya saing daerah.
Permasalahan dan Faktor yang Mempengaruhi Penyelenggaraan Pemerintahan Daerah Bidang Pendidikan, Kesehatan, Dan Sosial Di Kota Serang.

Dijelaskan bahwa urusan konkuren yaitu urusan pemerintahan yang dibagi antara pemerintah pusat dan daerah provinsi dan daerah kabupaten/kota. Berikut ini tabel yang menjelaskan skema urusan pemerintahan berdasarkan konkuren.

Tabel 2. Skema Urusan Pemerintahan Konkuren.

\begin{tabular}{|c|c|c|}
\hline \multicolumn{2}{|c|}{ Wajib } & Pilihan \\
\hline $\begin{array}{c}\text { Berkaitan } \\
\text { Dengan } \\
\text { Pelayanan Dasar }\end{array}$ & $\begin{array}{c}\text { Tidak Berkaitan } \\
\text { Dengan Pelayanan } \\
\text { Dasar }\end{array}$ & $\begin{array}{c}\text { Potensi dan } \\
\text { Keunggulan Daerah }\end{array}$ \\
\hline $\begin{array}{l}\text { 1. Pendidikan; } \\
\text { 2. Kesehatan; } \\
\text { 3. PU PR; } \\
\text { 4. Sosial; } \\
\text { 5. Perumahan } \\
\text { Rakyat dan } \\
\text { Kawasan } \\
\text { Permukiman; } \\
\text { 6. Ketertiban } \\
\text { Umum dan } \\
\text { Perlindungan } \\
\text { Masyarakat. }\end{array}$ & $\begin{array}{l}\text { 1. Tenaga kerja; } \\
\text { 2. Pemberdayaan } \\
\text { perempuan dan } \\
\text { perlindungan } \\
\text { anak; } \\
\text { 3. Pangan; } \\
\text { 4. Pertanahan; } \\
\text { 5. Lingkungan } \\
\text { hidup; } \\
\text { 6. Adm. } \\
\text { Kependidikan dan } \\
\text { Pencatatan Sipil; } \\
\text { 7. Pengendalian } \\
\text { Pendudukan dan } \\
\text { KB; } \\
\text { 8. Perhubungan; } \\
\text { 9. Kominfo; } \\
\text { 10. Koperasi dan } \\
\text { UKM; } \\
\text { 11. Penanaman } \\
\text { Modal; } \\
\text { 12. Kepemudaan dan } \\
\text { Olahraga; } \\
\text { 13. Persandian; } \\
\text { 14. Kebudayaan; } \\
\text { 15. Perpustakaan dan } \\
\text { kearsipan; }\end{array}$ & $\begin{array}{l}\text { 1. } \text { Kelautan dan } \\
\text { 2. Perikanan; } \\
\text { 3. Pertanian; } \\
\text { 4. Kehutanan; } \\
\text { 5. Energi dan } \\
\text { Sumber Daya } \\
\text { Mineral; } \\
\text { 6. Perdagangan; } \\
\text { 7. Perindustrian; } \\
\text { 8. Transmigrasi. }\end{array}$ \\
\hline
\end{tabular}

Diakui bahwa penyelenggaraan pemerintahan daerah sedikit banyaknya dipengaruhi oleh faktor-faktor. Faktor Pertama adalah politik hukum. Politik hukum sebagai kebijakan dasar penyelenggaraan negara atau daerah dan 
begitu mempengaruhi karena kondisi politik di daerah tersebut. ${ }^{29}$ Faktor Kedua, dipengaruhi pula oleh kondisi kinerja keuangan pemerintahan daerah yang diketahui sumber pendapatan daerah kota serang paling banyak bukan dari Pendapatan Asli Daerah (PAD) melainkan dari dana perimbangan. Dijelaskan bahwa dana perimbangan terdiri dari Dana Bagi Hasil, Dana Alokasi Umum (DAU) dan Dana Alokasi Khusus (DAK) baik itu dari Pemerintah Pusat dan Pemerintah Provinsi. ${ }^{30}$ Faktor Ketiga, Kepemimpinan kepala daerah dalam memimpin dan inovasi dari daerah tersebut. Tiga faktor inilah yang menjadi sumber masalah utama dan berdasarkan pada kondisi nyata pemerintahan Kota Serang merupakan ibukota provinsi yang masih jauh dari harapan sebagai etalase peradaban.

Kondisi politik hukum, keuangan pemerintahan daerah, dan kepemimpinan kepala daerah dalam penyelenggaraan pemerintahan daerah secara langsung berdampak pada bidang pendidikan, kesehatan, dan sosial. Hal ini tercermin dari sektor kebijakan dan sektor bantuan yang mempengaruhi capaian Indeks Pembangunan Manusia (IPM) yang dibentuk oleh tiga dimensi dasar, yaitu dimensi kesehatan (tergambar dari Angka Harapan Hidup), dimensi pendidikan (tergambar dari Rata-rata Lama Sekolah, Angka Harapan Sekolah), dan dimensi ekonomi. Dengan kondisi yang begitu dipengaruhi oleh kondisi politik, tetapi kerja pemerintahan begitu dinamis dan nyatanya setiap tahun nilai IPM Kota Serang terus meningkat dari Tahun 2016 sebesar 71,09, meningkat menjadi 72,16 pada Tahun 2020, namun capaian tersebut masih tertinggal dari beberapa kabupaten/kota di Provinsi Banten

29 Agus Darmawan, "Politik Hukum Penguatan Desentralisasi Fiskal Dalam Meningkatkan Kesejahteraan Masyarakat Daerah," Fiat Justisia Jurnal Ilmu Hukum 8, no. 1 (2014): 115.

30 Keren Debora dkk, "Faktor-Faktor Yang Mempengaruhi Kinerja Keuangan Daerah Di Kota Manado," Jurnal Berkala Ilmiah Efisiensi 20, no. 2 (2020): 2 . atau bahkan lebih rendah dari rata-rata IPM Provinsi Banten pada Tahun 2020 yang sebesar 72,45 .

Dari pengamatan dilapangan berdasarkan data yang diperoleh didapatkan rumusan permasalahan yang berhubungan dengan penyelenggaraan pemerintahan daerah khususnya tentang pendidikan, sebagai berikut:

1. Masih rendahnya cakupan pendidikan anak usia dini, dimana Angka Partisipasi PAUD Tahun 2019 sebesar 89,93 persen;

2. Belum optimalnya penyelenggaraan pelayanan pendidikan dasar dan kesetaraan, dimana capaian untuk Harapan Lama Sekolah sebesar 12,78 Tahun (Tahun 2020), Angka Rata-rata Lama Sekolah sebesar 8,76 persen (Tahun 2020), Angka Melek Huruf sebesar 99,98 persen (Tahun 2019), APM SMP sederajat Tahun 2019 sebesar 99,45 persen;

3. Belum terpenuhinya sarana dan prasarana penunjang layanan pendidikan dasar, diantaranya gedung SD/MI berkondisi baik sebesar 94,25 persen dan gedung SMP/MTs berkondisi baik sebesar 94,00 persen pada Tahun 2019, serta jumlah dan kualifikasi guru dan tenaga kependidikan belum memenuhi standar, sebagai gambaran rasio rata-rata jumlah guru SD terhadap jumlah murid SD per kelas sebesar 1:40 yang seharusnya standar $1: 32$.

Kemudian pengamatan dilapangan juga menemukan permasalahan yang berhubungan dengan penyelenggaraan pemerintahan daerah khususnya tentang kesehatan, sebagai berikut:

1. Angka Usia Harapan Hidup (UHH) Tahun 2020 sebesar 68,00 tahun, dibawah rata-rata Provinsi Banten sebesar 69,96 tahun; 
2. Terbatasnya sarana dan prasarana kesehatan untuk akses pelayanan kesehatan dasar dan rujukan;

3. Belum optimalnya Perilaku Hidup Bersih dan Sehat (PHBS) di masyarakat;

4. Masih ditemukannya kasus Angka Kematian Ibu (AKI), Angka Kematian Bayi (AKB), gizi buruk (stunting) dan kasus penyakit menular, yaitu pada Tahun 2019 masih ditemukan jumlah kasus AKI sebanyak 23 kasus dan Tahun 2020 menurun yaitu sebanyak 17 kasus, AKB pada Tahun 2019 sebanyak 29 kasus $(0,22$ persen), persentase gizi buruk pada Tahun 2019 sebanyak 0,17 persen dan Tahun 2020 sebanyak 0,22 persen, cakupan Linakes (fasilitas kesehatan) sebesar 95,18 persen;

5. Masih belum idealnya jumlah tenaga dokter dan paramedik, yaitu rasio medis (dokter dan dokter gigi) per 1000 penduduk sebesar 0,0072 dan rasio paramedis (Bidan dan Perawat) per 1000 penduduk sebesar 0,0037 pada Tahun 2020;

6. Masih ada masyarakat yang belum menjadi peserta BPJS, sedangkan keikutsertaan masyarakat dalam BPJS terdapat pada Program Srategis Nasional (PSN), yaitu pada tahun 2019 target UHC sebesar 95 persen;

7. Terjadinya pandemi COVID-19 berpengaruh terhadap derajat kesehatan masyarakat Kota Serang dikarenakan penyebaran COVID-19 yang begitu tinggi dan berpotensi pada kualitas kesehatan masyarakat sampai hari ini.

Kemudian pengamatan dilapangan juga menemukan permasalahan yang berhubungan dengan penyelenggaraan pemerintahan daerah khususnya tentang sosial, sebagai berikut:
1. Rehabilitasi sosial dasar bagi penyandang disabilitas terlantar yang jauh dari target capaian;

2. Rehabilitasi sosial dasar untuk lanjut usia, gelandangan, dan kebencanaan terlantar yang belum maksimal dikarenakan tidak memiliki sarana dan prasarana, bahkan gedung dinas sosial kota serang sampai hari ini masih tidak permanen;

3. Persentasi penduduk miskin di kota serang ditahun 2020 mengalami penaikan sebesar 6.06 persen yang diakibatkan oleh pandemi COVID-19 dan naiknya angka pengangguran di kota serang menjadi 10,6 persen.

4. Menurunya anggaran dinas sosial kota serang pada tahun 2021 dikarenakan dampak refocosing yang disesuaikan dengan ketentuan perundang-undangan.

Dari uraian tersebut perlu sinkronisasi dengan visi dan misi dari kepala daerah terpilih periode 2018-2023 yang sangat perlu dimanifestasikan dalam RKPD dan RPJMD sehingga ditemukan solusi dari empat permasalahan tersebut dan perlu diketahui bahwa penyelenggaraan pemerintahan di daerah ada pada tanggung jawab kepala daerah yang berdasarkan asas desentralisasi, dekosentrasi, dan tugas pembantuan. ${ }^{31}$ Pemerintah dibentuk dan dipilih secara langsung berfungsi untuk melayani atau sebagai pelayanan masyarakat. ${ }^{32}$ Dijelaskan oleh Rasyid menyatakan bahwa fungsi-fungsi pemerintahan terbagi menjadi empat bagian, yaitu: a. Pelayanan (Public Service); b. Pembangunan (Development); c. Pemberdayaan (Empowering); d. Pengaturan (Regulation). ${ }^{33}$

$31 \quad$ Pasal 1 angka 9 pasal 5 ayat 4 Undang-Undang Nomor 23 Tahun 2014 tentang Pemerintahan Daerah, n.d.

32 Zaidan Nawawi, Manajemen Pemerintahan (Jakarta: PT. Raja Grafindo, 2015), 25.

33 Muhadam Labolo, Memahami Ilmu 
Rasyid mengemukakan bahwa untuk mengetahui suatu masyarakat, maka lihatlah pemerintahannya. Artinya, fungsi-fungsi pemerintahan yang dijalankan pada saat tertentu akan menggambarkan kualitas pemerintahan itu sendiri. Jika pemerintahan dapat menjalankan fungsifungsinya dengan baik, tugas pokok selanjutnya menurutnya adalah bagaimana pelayanan dapat membuahkan keadilan, pemberdayaan yang membuahkan kemandirian, serta pembangunan yang menciptakan kemakmuran. ${ }^{34}$

Permasalahan di Kota Serang yang bertahun-tahun tidak selesai diperiodesasi kepala daerah yang lama, dengan visi dan misi kepala daerah yang baru sedikit demi sedikit mulai terlihat perbaikan khususnya dalam penataan sumber daya manusia yang dintaranya dalam sektor pelayanan pendidikan, kesehatan, dan sosial yang walaupun belum sempurna dan diketahui dalam periodesasi kepala daerah yang terpilih saat ini telah mengeluarkan regulasi yang cukup efektif dengan adanya Perda Kota Serang Nomor 6 Tahun 2018 tentang Penyelenggaraan Pendidikan, kemudian sedang dalam pembahasan yaitu Raperda Kota Serang tentang Penyelenggaraan Kesehatan, dan dirasa perlu adanya pembaharuan Perda Kota Serang Nomor Nomor 6 Tahun 2016 tentang Penyelenggaraan Kesejahteraan Sosial sehingga menyesuaikan dengan visi dan misi kepala daerah, keterlibatan masyarakat yang lebih besar dan lebih pro kepada disabilitas.

Selanjutnya atas penyelenggaraan pemerintahan daerah yang dipengaruhi oleh faktor politik hukum, keuangan pemerintahan daerah, dan kepemimpinan kepala daerah yang semulanya merupakan hambatan, diperiodesasi saat ini dapat dirubah menjadi solusi yang efektif dalam menjalankan pemerintahan daerah dan tentu masyarakat punya harapan besar kota

Pemerintahan Suatu Kajian, Teori, Konsep, Dan Pengembangannya (Jakarta: PT. Raja Grafindo Persada, 2011), 32.

34 Labolo, 33. yang dicintainya lebih baik dan terlaksananya pemerintah daerah berdasarkan prinsip good governance.

\section{PENUTUP}

Undang-undang pemerintahan daerah yang terbaru terdapat aturan mengenai penyelenggaraan pemerintahan daerah berdasarkan urusan konkuren. Terkait ini ada empat pokok permasalahan yang terjadi di kota Serang. Pertama, Belum optimalnya kondisi dan ketersediaan infrastruktur wilayah; kedua, belum optimalnya inovasi dan rendahnya daya saing perekonomian daerah; ketiga, belum optimalnya penyelenggaraan tata kelola pemerintahan; keempat, belum optimalnya penyelenggaraan pemerintahan daerah bidang pendidikan, kesehatan, dan sosial. Meskipun bidang Pendidikan telah memiliki Perda Nomor 6 Tahun 2018 tentang Penyelenggaraan Pendidikan namun belum efektif dan efesien dalam urusan PAUD, bidang Kesehatan yang ternyata belum memiliki Perda tentang urusan kesehatan, sedangkan Perda Nomor 6 Tahun 2016 tentang Penyelenggaraan Kesejahteraan Sosial belum efektif dan efisien dalam masalah disabilitas dan anak jalanan. Penyelenggaraan pemerintahan daerah dipengaruhi oleh faktor-faktor antara lain: Pertama, politik hukum. Politik hukum sebagai kebijakan dasar penyelenggaraan negara atau daerah dan begitu mempengaruhi karena kondisi politik di daerah tersebut. Kedua, dipengaruhi pula oleh kondisi kinerja keuangan pemerintahan daerah yang diketahui sumber pendapatan daerah kota Serang paling banyak bukan dari Pendapatan Asli Daerah (PAD) melainkan dari dana perimbangan. Ketiga, Kepemimpinan kepala daerah dalam memimpin dan inovasi dari daerah tersebut. Oleh karena itu, pemerintah daerah harus segera merancang dan menata kembali program skala prioritas dalam rencana kerja setiap satu tahun yang dikenal dengan Rencana Kerja Pembangunan Daerah (RKPD). Maka dengan 
otonomi daerah dampak yang sangat besar bagi masyarakat dan pemerintahan daerah adalah terlaksananya pemerintah daerah berdasarkan prinsip good governance.

\section{DAFTAR PUSTAKA}

Abdullah, Rozali. Pelaksanaan Otonomi Luas Dengan Pemilihan Kepala Daerah Secara Langsung. Jakarta: PT Raja Grafindo Persada, 2005.

Asshiddiqie, Jimly. Konstitusi Dan Konstitualisme. Jakarta: Konstitusi Press, 2006.

-. Pengantar Ilmu Hukum Tata Negara. Jakarta: Rajagrafindo Persada, 2015.

_. Pengantar Ilmu Hukum Tata Negara. Jakarta: Sekretariat Jenderal dan Kepaniteraan MK RI, 2016.

-. Perihal Undang-Undang. Jakarta: Rajawali Pres, 2011.

Darmawan, Agus. "Politik Hukum Penguatan Desentralisasi Fiskal Dalam Meningkatkan Kesejahteraan Masyarakat Daerah." Fiat Justisia Jurnal Ilmu Hukum 8, no. 1 (2014).

Diantha, I.Made Pasek. Metodologi Penelitian Hukum Normatif Dalam Justifikasi Teori Hukum. Jakarta: Prenada Media, 2016.

dkk, Keren Debora. "Faktor-Faktor Yang Mempengaruhi Kinerja Keuangan Daerah Di Kota Manado." Jurnal Berkala Ilmiah Efisiensi 20, no. 2 (2020).

dkk, Philipus Hadjon M. Pengantar Hukum Administrasi Indonesia. Vol. IX. Yogyakarta: Gajah Mada University Press, 2005.

Dossy Iskandar Prasetyo dan Bernard L, Ilmu Negara. Surabaya: Srikandi, 2005.

Fauzi, Achmad. "Otonomi Daerah Dalam Kerangka Mewujudkan Penyelenggaraan Pemerintahan Daerah Yang Baik." Jurnal Spektrum Hukum 16, no. 1 (2019).
G, Jopinus Saragih. "Reformasi Aparatur Negara Untuk Melaksanakan Tata Kelola Pemerintahan Yang Baik Dan Benar (Good Governance." Majalah Ilmiah Widya 29, no. 319 (April 2012).

H, Jeddawi Murtir. Negara Hukum Good Governance Dan Korupsi Di Daerah. Yogyakarta: Total Media, 2011.

Hariyanto, Hariyanto. "Pembangunan Hukum Nasional Berdasarkan Nilai-Nilai Pancasila." Volksgeist: Jurnal Ilmu Hukum Dan Konstitusi 1, no. 1 (June 7, 2018): 53-63. https://doi.org/10.24090/volksgeist.v1i1.1731.

Huda, Ni'matul. Hukum Pemerintahan Daerah. Bandung: Nusamedia, 2010.

"Kota Serang Dinilai Belum Layak Jadi Ibu Kota Provinsi | Republika Online.” Accessed June 21, 2021. https://www. republika.co.id/berita/q2e19d430/kota-serang-dinilai-belum-layak-jadi-ibukota-provinsi.

"Kota Tak Ideal, Pemkot Serang Salahkan Provinsi Banten | Republika Online." Accessed June 21, 2021. https://www. republika.co.id/berita/q54lww377/kota-tak-ideal-pemkot-serang-salahkanprovinsi-banten.

Labolo, Muhadam. Memahami Ilmu Pemerintahan Suatu Kajian, Teori, Konsep, Dan Pengembangannya. Jakarta: PT. Raja Grafindo Persada, 2011.

Mahmuzar. "Model Negara Kesatuan Republik Indonesia Di Era Reformasi." Jurnal Hukum Dan Pembangunan 50, no. 2 (2020).

Manan, Bagir. Perjalanan Historis Pasal 18 UUD 1945. Jakarta: UNISKA, 1993.

Nawawi, Zaidan. Manajemen Pemerintahan. Jakarta: PT. Raja Grafindo, 2015.

Neta, Yulia. "Model Tata Kelola Administrasi Pemerintahan Yang Baik Di Daerah Oto- 
nom Baru." Fiat Justitia Jurnal Ilmu Hukum 6, no. 2 (Agustus 2012).

PP Nomor 38 Tahun 2007 tentang Pembagian Urusan Pemerintahan Antara Pemerintah, Pemerintahan Daerah Provinsi, Dan Pemerintahan Daerah Kabupaten/Kota, n.d.

Qamar, Nurul. Hak Asasi Manusia Dalam Negara Hukum Demokrasi. Jakarta Timur: Sinar Grafika, 2013.

Rancangan Perda Kota Serang Tahun 2021 Tentang Perubahan Atas Peraturan Daerah Kota Serang Nomor 3 Tahun 2019 Tentang RPJMD Kota Serang 20182023, n.d.
Riyanto, Astin. Aktualisasi Negara Kesatuan Setelah Perubahan Atas Pasal 18 Undang-Undang Dasar Negara Republik Indonesia Tahun 1945. Bandung: Disertasi Universitas Padjajaran, 2006.

Sadjijono. Bab-Bab Pokok Hukum Administrasi. Yogyakarta: PRESSindo, 2008.

Undang-Undang Nomor 23 Tahun 2014 tentang Pemerintahan Daerah, n.d.

Wahidin, Samsul. Distribusi Kekuasaan Negara Indonesia. Yogyakarta: Pustaka Pelajar, 2014.

Zainuddin Ali, M. Metode Penelitian Hukum. Jakarta: Sinar Grafika, 2013. 